\title{
TƯ LIÊUU VÀ NHẬN THỨC BƯớC ĐÀU VỀ CUỘC THÁM SÁT DI TÍCH HANG NÚI LỬA C6-1 Ở KRÔNG NÔ, TỈNH ĐẮK NÔNG
}

\author{
Lê Xuân Hưng ${ }^{\mathrm{a}}$, La Thế Phúc ${ }^{\mathrm{b}}$, Phạm Thị Phương Thảoa, \\ Vũ Tiến Đức ${ }^{c}$, Nguyễn Trung Minh ${ }^{b}$
}

${ }^{a}$ Khoa Lịch sử, Trường Đại học Đà Lạt, Lâm Đồng, Việt Nam

${ }^{b}$ Bảo tàng Thiên nhiên Việt Nam, Viện Hàn lâm Khoa học và Công nghệ Việt Nam, Hà Nội, Việt Nam 'Viện Khoa học Xã hội vùng Tây Nguyên, Viện Hàn lâm Khoa học Xã hội Việt Nam, Đắk Lắk, Việt Nam

*Tác giả liên hệ: Email: hunglx@dlu.edu.vn

Lịch sử bài báo

Nhận ngày 10 tháng 09 năm 2018

Chỉnh sửa ngày 16 tháng 09 năm 2018| Chấp nhận đăng ngày 18 tháng 09 năm 2018

\section{Tóm tắt}

Hệ thống hang động núi lưa ở huyện Krông Nô, tỉnh Đắk Nông không chỉ có giá trị về mặt địa chất mà còn hàm chứa nhũng giá trị độc đáo về mặt sinh thái và văn hóa. Ở Việt Nam, tù giai đoạn so kỳ Đá cũ đến so kỳ Đá móit, các nhà khảo cổ học Việt Nam đã phát hiện và nghiên cứu trên 200 hang động núi đá vôi có người tiền sủ cu trú. Tuy nhiên, việc tìm thấy dấu vết của nguoời tiền sứ cu trú trong hang động núi lưa ở Krông Nô lai là lần đầu tiên ở Việt Nam và Đông Nam Á. Bài viết này sẽ giới thiệu tu liệu về nhũng dấu vết cu trú và các hoạt động chế tác công cu đá của nguoòi tiền sử, niên đại tuoong đối khoảng 6,000BP4,000BP (Before Present - BP) thông qua việc điều tra 10 hang động và khai quật hang động núi lưa C6-1 ở Krông Nô năm 2017. Kết quả này sẽ góp phần tích cực cho việc nghiên cứu diễn trình lịch sử văn hóa các cộng đồng cu dân tiền sủ ở Đắk Nông nói riêng và Tây Nguyên nói chung; Góp phần tu liệu xây dụng hồ sơ "Công viên Địa chất Núi lưa Krông Nô"; Bảo tồn và phát huy di sản văn hóa khảo cổ cũng nhu phát triển kinh tế xã hội ở Đắk Nông.

Từ khóa: Công viên Địa chất Núi lửa Krông Nô; Hang động núi lửa ở Việt Nam; Người thời tiền sử ở Krông Nô.

Mã số định danh bài báo: http://tckh.dlu.edu.vn/index.php/tckhdhdl/article/view/507

Loại bài báo: Bài báo nghiên cứu gốc có bình duyệt

Bản quyền @ 2018 (Các) Tác giả.

Cấp phép: Bài báo này được cấp phép theo CC BY-NC-ND 4.0 


\title{
PRELIMINARY FINDINGS AND AWARENESS FROM THE C6-1 ARCHAEOLOGICAL EXPLORATION IN KRONGNO, DAKNONG PROVINCE
}

\author{
Le Xuan Hung ${ }^{\mathrm{a}}$, La The Phuc ${ }^{\mathrm{b}}$, Pham Thi Phuong Thao ${ }^{\mathrm{a}}$, \\ Vu Tien Ducc, Nguyen Trung Minh ${ }^{b}$
}

${ }^{a}$ The Faculty of History, Dalat University, Lamdong, Vietnam

${ }^{b}$ The Vietnam National Museum of Nature, Vietnam Academy of Science and Technology, Hanoi, Vietnam

${ }^{c}$ The Institute of Social Sciences in the Central Highlands, Vietnam Academy of Social Sciences,

Daklak, Vietnam

"Corresponding author: Email: hunglx@dlu.edu.vn

Article history

Received: September $10^{\text {th }}, 2018$

Received in revised form: September $16^{\text {th }}, 2018 \mid$ Accepted: September $18^{\text {th }}, 2018$

\begin{abstract}
The volcanic cave system in Krongno district is not only of geological interest, but it also possesses unique ecological and cultural value. Vietnamese archaeologists have discovered and studied over 200 limestone caves with prehistoric dwellings dating from the early period of the Old Stone Age to the New Stone Age. However, the traces of prehistoric people residing in the Krongno volcanic cave (Daknong) are the first to be discovered in a volcanic cave in Southeast Asia. This paper presents the preliminary findings regarding the discovery of dwellings and stone tool processing of prehistoric people living around 6,000 - 4,000 years ago obtained from the investigation of 10 caves and the excavation of the C61 volcanic cave in Krongno in 2017. These findings positively contribute to the study of the cultural history of prehistoric communities in Daknong province, in particular, and the Central Highlands in general. In addition, the research contributes to the construction of the "Krongno Volcanic Geopark" and the preservation and promotion of archaeological heritage as well as the socio-economic development of Daknong province.
\end{abstract}

Keywords: Krongno Volcanic Geopark; Prehistoric people in Krongno; Volcanic cave system in Vietnam.

Article identifier: http://tckh.dlu.edu.vn/index.php/tckhdhdl/article/view/507

Article type: (peer-reviewed) Full-length research article

Copyright $\odot 2018$ The author(s).

Licensing: This article is licensed under a CC BY-NC-ND 4.0 


\section{LờI MỞ ĐẦ}

Ở Việt Nam cũng như trên thế giới, để bảo tồn và phát huy những giá trị đặc biệt quý hiếm về quá trình thành tạo trái đất rất được quan tâm trong các lĩnh vực như: Địa chất, sinh thái, văn hóa, khảo cổ học... Tỉnh Đắk Nông là một trong những địa phương được sở hữu những di sản ấy. Hiện nay, tỉnh Đắk Nông đang phối kết hợp với Bảo tàng Thiên nhiên Việt Nam xây dựng hồ sơ trình UNESCO công nhận "Công viên Địa chất Núi lửa Krông Nô" (Krongno Volcanic Geopark - KVG). Những di tồn về các hoạt động của núi lửa nói chung, hệ thống hang động nói riêng ở Krông Nô không chỉ có một số giá trị khoa học quan trọng về địa chất, mà còn cả các giá trị độc đáo về văn hoá, sinh thái và khảo cổ học, phù hợp với tiêu chí cho một công viên địa chất toàn cầu mà UNESCO đề xuất (UNESCO, 2009).

Theo quy hoạch, diện tích dự kiến cho KVG là $3,148 \mathrm{~km}^{2}$, gồm toàn bộ các huyện Krông Nô, Cư Jút, Đắk Mil và một số xã phụ cận thuộc các huyện Đắk Song (xã Đắk Hòa, Đắk Môn, Nâm N'Jang), huyện Đắk Glong (xã Quảng Sơn). Kết quả khảo sát ban đầu cho thấy trong địa bàn đã phát hiện gần 100 hang động núi lửa, nhưng trước năm 2017 chưa có phát hiện và công bố nào về di tích khảo cổ trong hang động. Nhu cầu đặt ra, để xây dựng hồ sơ công viên địa chất, yếu tố văn hóa là một trong những tiêu chí quan trọng, vì vậy việc tìm hiểu về những dấu vết của con người là cần thiết. Những phát hiện đầu tiên được đăng tải, trong công bố này đã giới thiệu một số dấu vết của con người thời tiền sử tại các hang $\mathrm{C} 1, \mathrm{C} 3, \mathrm{C} 4, \mathrm{C} 6, \mathrm{C} 6$ ', C6-1. Hiện vật thu được là các công cụ ghè đẽo, công cụ hình bầu dục, mảnh tước, gốm tiền sử... Đặc biệt tại hang C6', trên hai gò đá xếp hình tròn, gò cao đã phát hiện một số đoạn xương chi và răng. Theo nhận định ban đầu thì rất có thể đó là di cốt của người tiền sử (La \& ctg., 2017). Những phát hiện trên là cơ sở để các nhà địa chất, khảo cổ học tiếp tục tìm hiểu về phạm vi phân bố của con người tiền sử trong các hang động núi lửa ở KVG; Tìm hiểu về tính chất, niên đại và các giá trị lịch sử, văn hóa của các di tích này như thế nào? Để góp phần trả lời các câu hỏi trên, đầu năm 2017, các nhà địa chất ở Bảo tàng Thiên nhiên Việt Nam và các nhà khảo cổ ở Viện Khảo cổ học, Viện Khoa học Xã hội vùng Tây Nguyên, và Trường Đại học Đà Lạt tiến hành điều tra và phát hiện mới một số di tích khảo cổ tiền sử hang động trên địa bàn huyện Krông Nô (Nguyễn, Phan, Lê, \& Vũ, 2017).

Tháng 2 năm 2017, hang C6-1 đã được đào thám sát. Kết quả thu được từ việc điều tra, thám sát này đã góp phần xác định sơ bộ đặc điểm phân bố, nội dung, tính chất, niên đại một số di tích khảo cổ hang động cũng như những giá trị lịch sử văn hóa của các di tích này trong bối cảnh rộng hơn. Đây cũng là cơ sở cho việc biên soạn lịch sử giai đoạn xa xưa ở vùng đất này và góp phần tư liệu để xây dựng hồ sơ công viên địa chất toàn cầu KVG. Đến tháng 3 năm 2018, chúng tôi tiếp tục khai quật hang C6-1 theo tinh thần của giấy phép do Bộ trưởng Bộ Văn hóa - Thể thao và Du lịch cấp (Quyết định Số 52/QĐ-BVHTTDL). Trong quá trình khai quật, những thông tin về di cốt người thời tiền sử đã được một số trang nhật báo đưa tin; Đáng chú ý là các bài viết về cuộc phỏng vấn chúng tôi tại hiện trường đăng tải trên Tuổi trẻ Online, Tiền phong Online và Báo Đắk Nông của hai tác giả Hoàng Thiên Nga và Vũ Hà. Tuy nhiên, kết quả của đợt 
khai quật này đang trong quá trình chỉnh lý và nghiên cứu sâu để hoàn thiện báo cáo trình Bộ Văn hóa - Thể thao và Du lịch.

Trong bài báo này, chúng tôi chỉ giới thiệu kết quả đào hố thám sát (tháng 2 năm 2017) và đưa ra một vài đánh giá, nhận thức về vấn đề này. Những nghiên cứu mới về hang C6-1 năm 2018 sẽ được công bố chính thức khi có đầy đủ kêt quả nghiên cứu về đặc trưng, các giai đoạn phát triển, niên đại $\mathrm{C} 14$, di cốt người (chủ nhân), phân tích từ cảm và bào tử phấn hoa...

\section{CÁC DI TÍCH KHẢO CỔ HANG ĐỘNG VÀ HANG C6-1}

\subsection{Một số đặc điểm của di tích khảo học hang động}

Lịch sử thành tạo các hang động núi đá vôi khác với hang động núi lửa. Đối với các hang karst (hang động núi đá vôi) được hình thành trong tự nhiên, khi mà một lượng axit cacbonic trong nước mưa mang một lượng $\mathrm{CO}_{2}$, khi nước mưa đi qua đất (nước dưới đất), hấp thụ thêm $\mathrm{CO}_{2}$ sẽ có tính axit mạnh hơn, dễ dàng hòa tan canxit (loại khoáng chất chủ yếu trong đá vôi) và mang đi theo dòng chảy. Theo thời gian, đá dọc khe nứt (hoặc lỗ rỗng) dần bị hòa tan mở rộng và kết nối lại với nhau để tạo ra các khoảng trống lớn hơn. Các dòng chảy mở rộng khoảng trống này thường xảy ra tại hoặc ngay dưới gương nước ngầm, nơi nước lưu thông theo chiều ngang (tương ứng với mực xâm thực cơ sở địa phương). Khi các khoảng trống mở rộng đủ lớn, con người có thể đi qua được gọi là "hang động" (La, Tachihara, Honda, Trương, \& Lương, 2015). Trong lịch sử cư trú của nhân loại, hang động được xem là ngôi nhà lý tưởng con người thời Tiền sử. Ở Việt Nam, phát hiện sớm nhất là dấu tích hóa thạch người đứng thẳng (Homo erectus) trong hang động ở Thẩm Hai và Thẩm Khuyên, nơi có niên đại khoảng 0.5 triệu năm trước. Cư dân chiếm cư phổ biến nhất trong các hang động đá vồi ở Việt Nam là người thuộc giai đoạn sơ kỳ Đá mới với gần 200 di tích hang động, phân bố chủ yếu ở miền Bắc và Bắc Trung bộ Việt Nam (Nguyễn \& ctg., 2016).

Đối với việc thành tạo các hang động núi lửa lại hoàn toàn khác, quá trình ấy không phải là những tác động của dòng nước mưa khoét dòng, hay dạng dòng nước chảy qua như một số hang động ở Tràng An (Ninh Bình), Con Moong (Thanh Hóa) mà nó là quá trình phun trào từ núi lửa tạo ra các dòng dung nham. Sau đó, bề mặt của nó nguội lạnh dần dần và tạo thành ống dung nham đông cứng ở ngoài vỏ, ở phía trong ống dung nham nóng vẫn tiếp tục chảy. Khi dòng dung nham ban đầu phun trào thoát ra miệng núi lửa sẽ tạo thành một ống dung nham, còn miệng núi lửa trở thành một hố sụt từ mặt xuống lòng hang. Như vậy, việc hình thành hang động núi lửa chính là sự cắt nguồn dòng chảy và co rút của dòng dung nham.

Ở khu vực huyện Krông Nô (Đắk Nông) đã tìm thấy các dạng hang hình ống. Có hang dài và nằm sâu dưới mặt đất, có hệ thống các hang với nhiều cửa ăn thông lên mặt đất. Các hang ở vùng Đắk Nông đa số dài trên $500 \mathrm{~m}$ và có cửa thông thoáng. Đó là điều kiện tiên quyết để con người thời tiền sử lựa chọn làm nơi cư trú. Trước năm 2017, ở Việt Nam chưa phát hiện được một hang động núi lửa nào có dấu tích hoạt động của con người thời tiền sử. Đầu năm 2017, một loạt hang động núi lửa vùng Đắk Nông được 
tìm thấy. Trong đó, các hang động có dấu tích cư trú của con người thời tiền sử chủ yếu ở khu C (Hình 1) (La \& ctg., 2017). Có thể nói, những phát hiện này là bước mở đầu quan trọng cho việc nghiên cứu khảo cổ học hang động núi lửa ở Việt Nam.

Như đã trình bày ở trên, quá trình khảo sát các di tích hang động ở khu $\mathrm{A}$, khu $\mathrm{B}$ và khu $\mathrm{C}$, các nhà nghiên cứu phát hiện mới một số di tích khảo cồ hang động núi lửa khu $\mathrm{C}$. Đó là các hang có miệng thứ sinh; Các hang này thường có cửa cao và rộng, ánh sáng chiếu sâu vào lòng hang. Hang có nhiều ngách, nhiều cửa, nên lòng hang thông thoáng và đường lên xuống hang khá dễ dàng. Hệ thống các hang động phân bố gần các con suối đổ nước ra sông Srepôk, nơi có nguồn nguyên liệu đá để chế tác công cụ và nguồn thủy sinh dồi dào cung cấp thực phẩm cho con người, đặc biệt là nguồn nước sinh hoạt cho cư dân tiền sử sống trong các hang động.

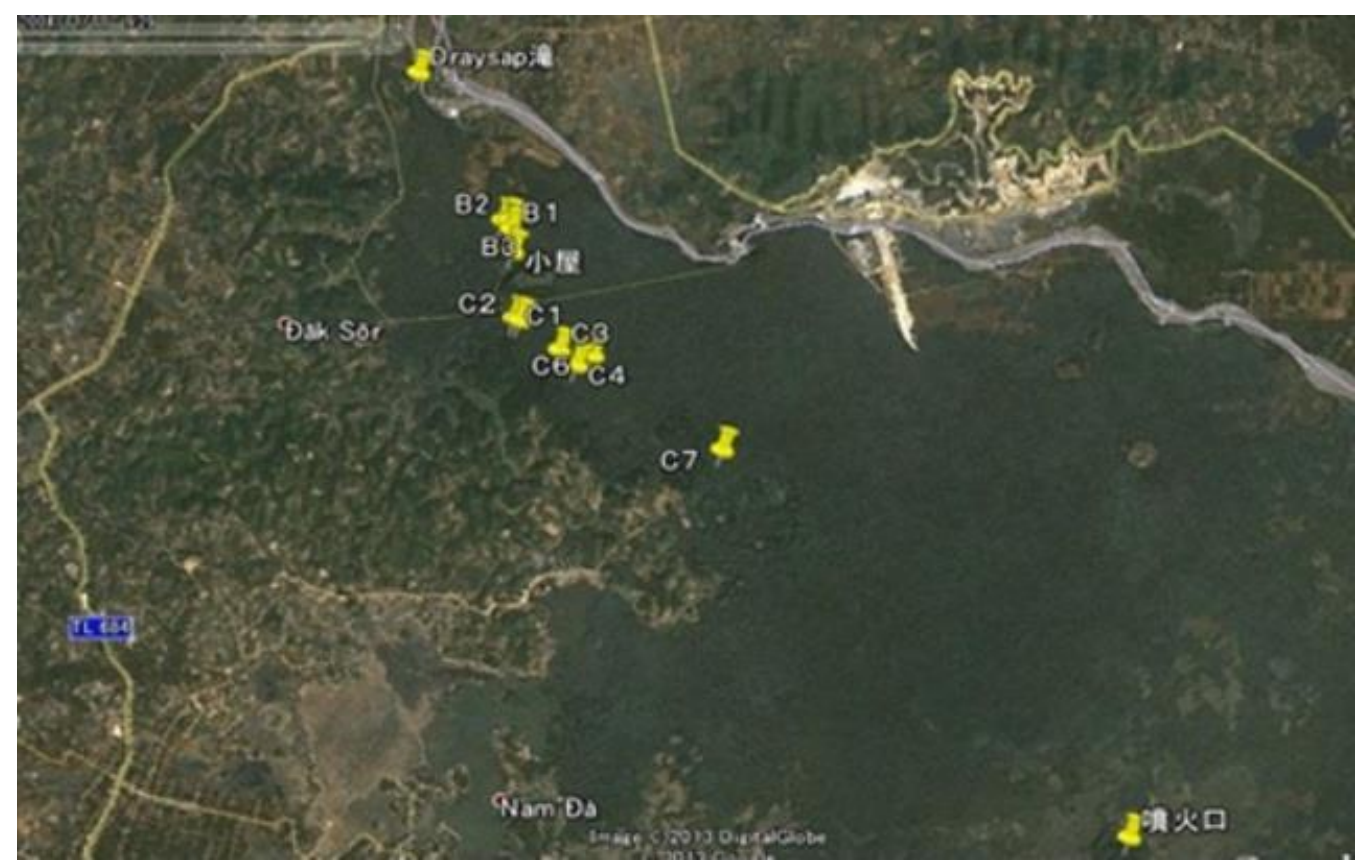

Hình 1. Các hang động tiêu biểu ở Krông Nô, Đắk Nông

Nguồn: Nguyễn \& ctg. (2017)

\section{2. Đặc điểm hang C6-1 và kết quả khảo sát bước đầu}

Hang C6-1 có tọa độ 12030'47.6”; 107054'06.2”; độ cao tuyệt đối so với mực nước biển là $346 \mathrm{~m}$. Hang C6-1 có chiều dài là $293 \mathrm{~m}$, với 3 cửa hướng khác nhau: Cửa 1 quay về phía Tây Nam, nơi phát hiện công cụ đá, mảnh gốm và được đào thám sát. Cửa 2 quay về phía Nam, dân địa phương đã khai thác phân dơi, làm bật lên một số di vật khảo cổ. Cửa 3 quay về phía Đông Bắc, ở đây cũng bị đào lấy phân dơi và phát hiện mảnh tước. Trong hang còn dấu tích của cấu trúc đá được xếp hình tròn, gò cao giống như hang C6'. Rất có thể cấu trúc gò liên quan đến mộ táng. Nhìn chung, nhánh hang cửa hướng Đông Bắc và hướng Nam thấp, ẩm ướt và bị xâm phạm bởi hoạt động khai thác phân dơi đã lộ rõ nền dung nham. Với cửa hang hướng Tây Nam thì cao hơn, hang 
thoáng, trước cửa hang là nền đất cao khoảng $2-2.5 \mathrm{~m}$ so với nền hang bên trong, nền gần cửa hầu như không bị xâm phạm.

Kết quả khảo sát hang C6-1 (tháng 1 năm 2017): Khu vực cửa hang hướng Đông Bắc phát hiện được một mảnh tước thứ bằng đá basalte, mặt bụng phẳng, mặt lưng lồi và có nhiều vết ghè trước đó. Khu vực cửa hướng Nam đã thu thập trên bề mặt một công cụ đá hình bầu dục, bốn mảnh tước; Ba viên cuội sông, là những viên cuội sông được đưa vào hang, còn nguyên vẹn, hình bầu dục hoặc hình cầu dẹp, không có vết chế tác. Ở cửa hướng Tây Nam thu thập được nhiều hiện vật nhất, gồm 30 di vật đá, gồm: 01 công cụ hai rìa, 01 mũi nhọn, 01 phác vật rìu, 01 công cụ cắt, 01 bàn mài, 01 mảnh rìu mài, 01 công cụ hình rìu, 02 công cụ hình bầu dục, 01 rìu mài lưỡi, 01 phác vật, 04 đá nguyên liệu và 15 mảnh tước; Đồ gốm có 01 mảnh, là loại gốm có màu nâu đỏ, cứng, mỏng, áo gốm bong tróc lộ xương gốm màu nâu đỏ pha lẫn cát thô. Độ nung và độ kết dính của các thành phần trong mảnh gốm thấp, thân dày $0.2 \mathrm{~cm}$.

\subsection{Kết quả thám sát hang C6-1}

\subsubsection{Vài nét về hố thám sát}

Tháng 2 năm 2017, chúng tôi đã đào thám sát ở gần cửa nhánh Tây Nam của hang C6-1. Nhánh hang này có cửa hình bán khuyên, rộng $15 \mathrm{~m}$, cao $3.2 \mathrm{~m}$. Hang ăn sâu vào trong $32 \mathrm{~m}$, sau đó quẹo trái và tiếp tục chạy vòng quanh khối đá basalte ở giữa. Ánh sáng hắt sâu vào lòng hang khoảng 10 - 15m (kể từ giọt mưa cửa hang), đặc biệt hang đón được nhiều ánh sáng vào buổi chiều, cửa cũng là phần cao nhất của hang. Trong khu vực này còn phủ lớp trầm tích đất phong hóa từ đá basalte, chứa dấu tích tầng văn hóa nguyên vẹn (in situ). Từ cửa hang, lòng hang thấp và dốc dần vào trong rồi lộ hẵn nền đá basalte. Trên mặt hang phát hiện rất nhiều công cụ đá ghè đẽo và mảnh gốm tiền sử.

Để đào hố thám sát kiểm tra địa tầng di tích và có hướng nghiên cứu lâu dài, chúng tôi chia độ rộng cửa hang $15 \mathrm{~m}$ thành 14 khoảng, mỗi khoảng $1 \mathrm{~m}$. Từ giới hạn cửa hang vào vách trong cùng dài khoảng $23 \mathrm{~m}$, chia thành 23 khoảng, mỗi khoảng rộng $1 \mathrm{~m}$. Hố thám sát $2 \mathrm{~m}^{2}(1 \mathrm{~m} \times 2 \mathrm{~m})$ ở tọa độ ô $\mathrm{D} 3$ và ô $\mathrm{D} 4$, đây cũng là tọa độ thống nhất trong đăng ký hiện vật thám sát.

\subsubsection{Cấu tạo địa tầng hố thám sát}

Hố thám sát tạm dừng lại sau 8 lớp đào, mỗi lớp từ $8-10 \mathrm{~cm}$, tổng độ sâu từ $70 \mathrm{~cm}-80 \mathrm{~cm}$. Căn cứ màu kết cấu và màu sắc đất, chúng tôi chia tầng văn hóa thành 2 mức sớm muộn, cấu tạo các mức như sau (Hình 2):

- Mức 1 (gồm các lớp đào): Lớp mặt, lớp 1 , và lớp 2, dày trung bình $30 \mathrm{~cm}$. Đất màu nâu, nâu sẫm, mịn, tơi xốp, vốn phong hóa từ basalte có lẫn mùn thực vật như lá và rễ cây. Trong mức này tìm thấy công cụ hình bầu dục có hình dáng ổn định, gốm mảnh tiền sử, xương các loài động vật nhỏ, ốc suối, vỏ trai, vỏ hến, công cụ mài toàn thân, mảnh tước, mũi tên đồng. Đồ đá và 
gốm ở mức này mang đặc trưng của giai đoạn hậu kỳ Đá mới, sơ kỳ Kim khí; Niên đại đoán định khoảng 5,000 năm đến trên dưới 4,000 năm BP.

- Mức 2: Gồm 6 lớp còn lại, từ lớp 3 đến lớp 8 , dày trung bình $50 \mathrm{~cm}$. Đất có kết cấu mịn và tơi, xốp vốn phong hóa từ đá basalte. Ở mức này có sự thay đổi màu sắc đất theo độ sâu lớp đào: Các lớp đào $3,4,5$ đất màu xám trắng và rất mịn, đến lớp 6 đất màu xám nâu, lớp 7 và lớp 8 có xám đỏ, nâu đỏ. Từ lớp 6 trở xuống của địa tầng mức 2 gặp một số hòn đá basalte to. Trong mức 2 không tìm thấy gốm tiền sử nhưng xương cốt động vật thường kích thước to hơn, ốc suối, trai xuất hiện nhiều hơn, công cụ ghè đẽo thô hơn, mật độ phân bố nhiều hơn. Những vết tích văn hóa ở đây phản ánh giai đoạn muộn của giai đoạn trung kỳ Đá mới; Niên đại đoán định khoảng 6,000 năm đến 5,000 năm $\mathrm{BP}$.

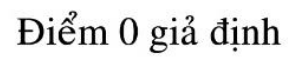
D3 D4

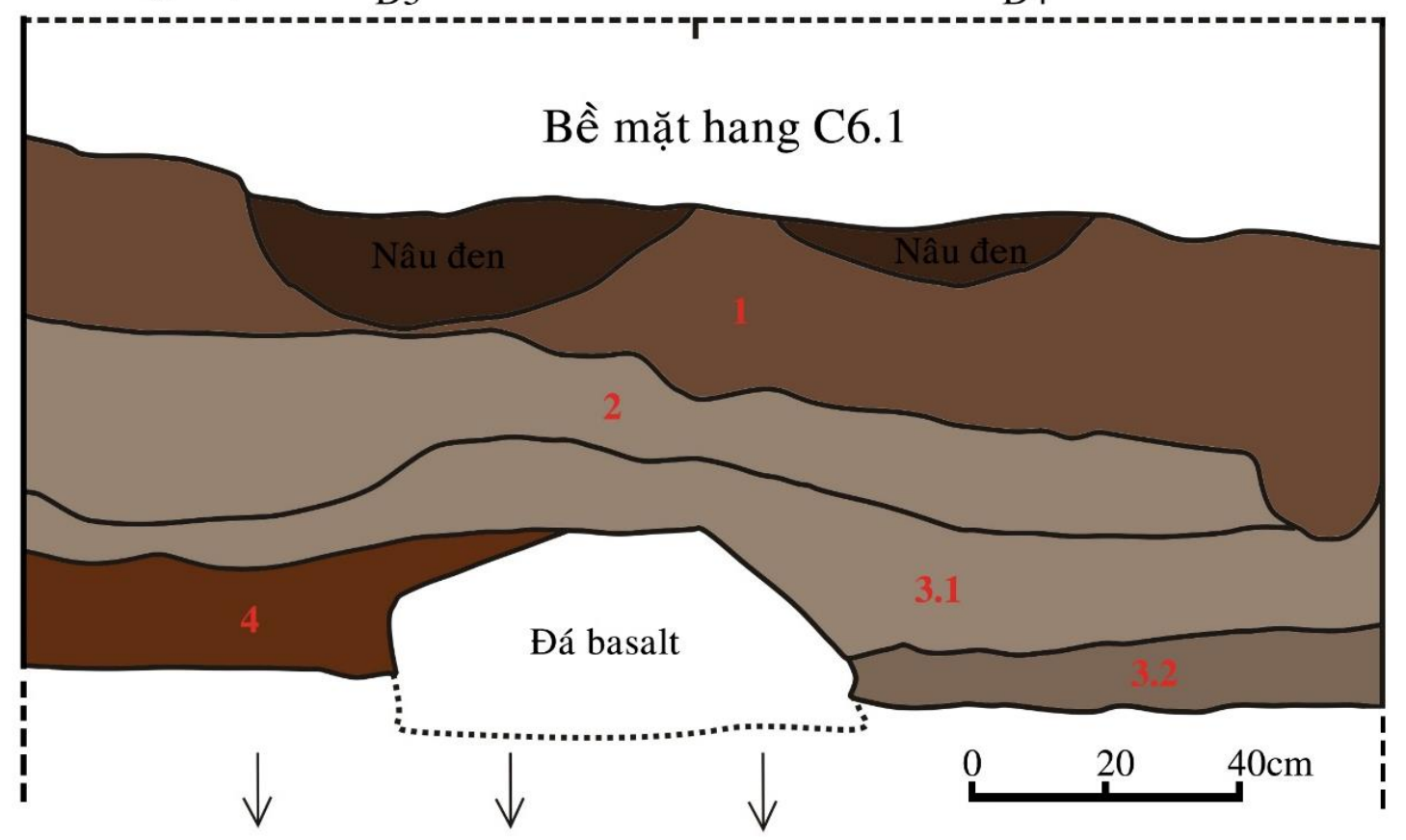

Hình 2. Vách bắc địa tầng hố thám sát hang C6.1

\subsubsection{Di tích}

\section{- Các tàn tích bếp và bếp liủa}

Trong hố thám sát phát hiện 2 hố đất đen, ký hiệu $F 1$ và $F 2$. Đây là vết tích của bếp lửa và dấu tích bữa ăn do con người nguyên thủy sử dụng còn để lại, chúng có một số đặc điểm sau: Hố đất đen $\mathrm{F} 1$ có hình gần tròn, phân bố ở các ô $\mathrm{C} 2,3$ và $\mathrm{D} 2,3$; Xuất lộ ngay từ bề mặt và có độ sâu $30 \mathrm{~cm}$ so với mặt hố. F1 có đường kính trung bình $60 \mathrm{~cm}$, hình lòng chảo, rộng ở trên, thu nhỏ dần và kết thúc ở lớp đào 3. Trong F1, đất màu nâu 
sẫm, tương đối xốp, lẫn ít rẽ cây. Giữa hố có vài cục đá basalt (đá basalt bọt), có vết tích than tro của bếp lửa. Hiện vật có đồ đá, mảnh gốm tiền sử, xương động vật (Hình 3).

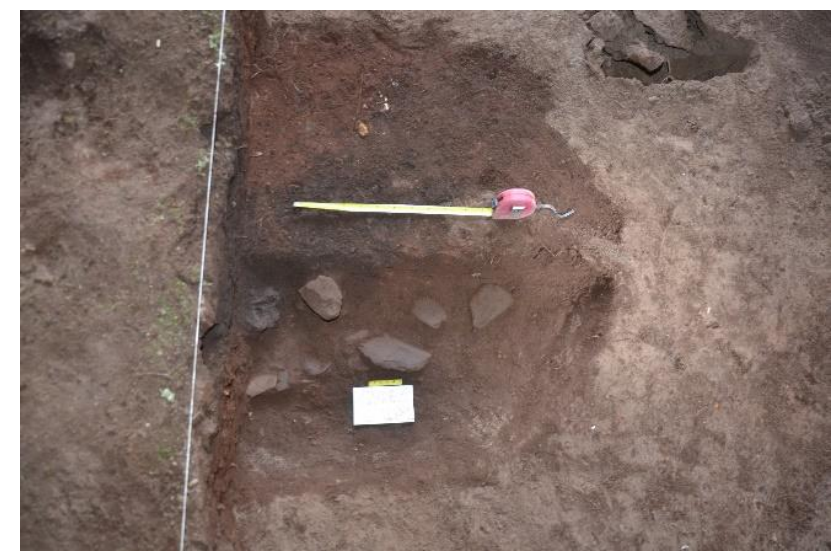

Hình 3. Hố đất đen F1 hang C6-1

Hố đất đen $\mathrm{F} 2$ có độ sâu khoảng $30 \mathrm{~cm}$, xuất hiện ngay từ bề mặt, $1 / 2$ của hố ăn vào vách $\mathrm{Nam}$; Hố phân bố ở sát vách ô $\mathrm{D} 3$, đường kính trung bình $50 \mathrm{~cm}$, dày ở giữa mỏng dần xung quanh. Trong F2 có một vài cục đá basalt khá lớn, chung quanh cục đá là dấu tích than tro vốn của bếp lửa, cùng một số mảnh gốm, mảnh xương động vật và vỏ nhuyễn thể (Hình 4).

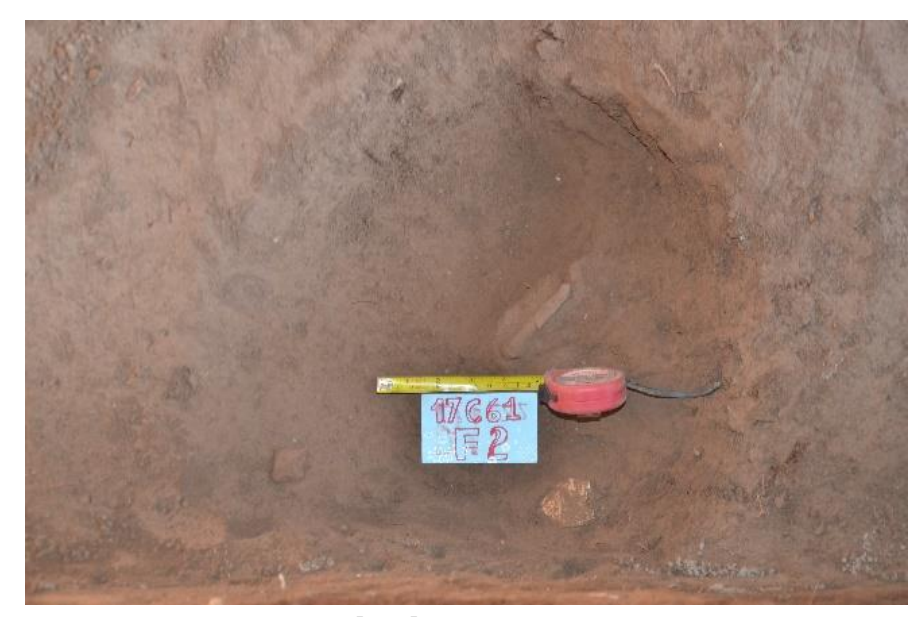

Hình 4. Hố đất đen F2 hang C6-1

- Các di tích động vật

Trong hố thám sát hang C6-1 với diện tích $2 \mathrm{~m}^{2}$, địa tầng dày $80 \mathrm{~cm}$, đã thu được 5,027 mảnh di cốt động vật và vỏ nhuyễn thể nước ngọt các loại. Với tư liệu hiện biểt, đây là di tích khảo cổ hang động núi lửa đầu tiên ở Việt Nam và Đông Nam Á được thám sát và cũng là di tích duy nhất tìm thấy khối lượng lớn di cốt động vật trong tầng văn hóa ở Tây Nguyên. Các di cốt này được chúng tôi chỉnh lý sơ bộ và Nguyễn Anh Tuấn, một chuyên gia về động vật học (Viện Khảo cổ học, Việt Nam) giám định. 
Các di cốt động vật và vỏ nhuyễn thể được thu thập và xử lý theo từng lớp đào, mỗi lớp dày trung bình $10 \mathrm{~cm}$. Các mẫu di cốt động vật và vỏ nhuyễn thể được định loại và đánh số cẩn thận theo trật tự bởi: Năm, di chỉ, ĐV-số thứ tự, lớp đào (17.C61.DDV001.L1). Đối với những hiện tượng khác biệt ở mỗi mặt bằng khai quật, được thu thập tách riêng và có thêm kí hiệu $\mathrm{F}$, như L1.F1 và L3.F2. Hầu hết mỗi mảnh xương răng còn đủ các đặc trưng hình thái giải phẫu phân loại có thể định loại đến mức loài/họ/bộ/lớp với các ghi chú về loại xương và vị trí đoạn xương còn lại, số lượng mảnh, các dấu vết bị cháy hoặc bị gặm, mòn do sử dụng (Hình 5).

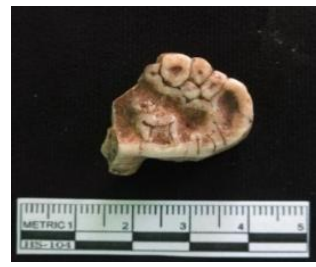

(a)

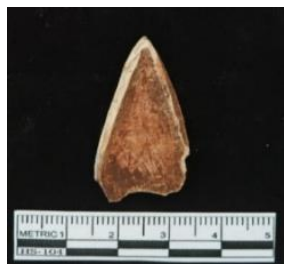

(d)

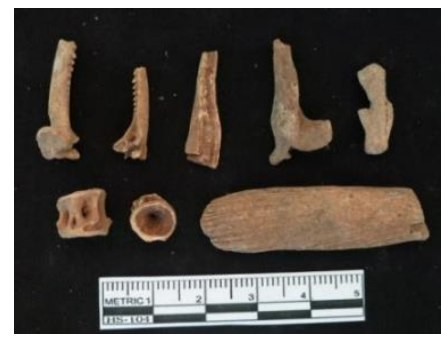

(g)

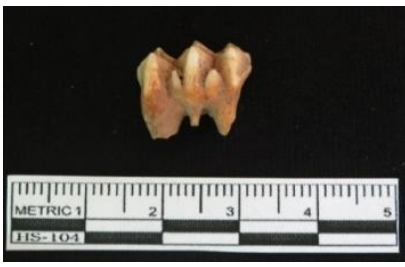

(b)

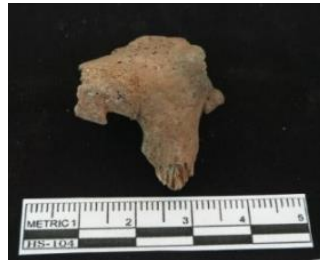

(e)

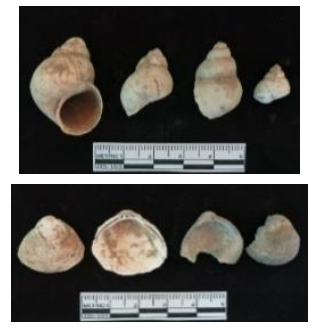

(h)

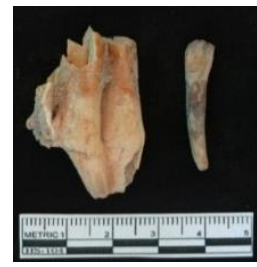

(c)

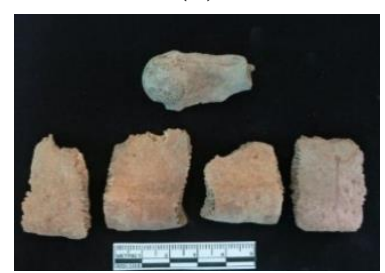

(f)

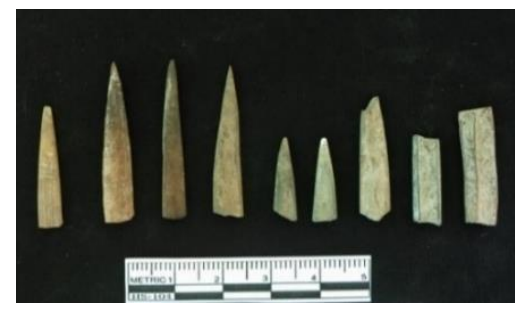

(i)

\section{Hình 5. Xương răng động vật}

Ghi chú: a) Răng lợn; b) Răng hươu vàng; c) Răng hươu; d) Răng tê giác; e) Mảnh sọ khỉ;

f) Xương, mảnh mai rùa; g) Xương cá; $h$ ) Vỏ nhuyê̂n thể; và i) Công cụ xương mài.

Trong tổng số 5,027 mảnh di cốt động vật, hầu như tất cả các xương răng đều đã bị vỡ vụn. Phần lớn các xương không còn nhiều đặc điểm giải phẫu để định loại chủng loài, nên chúng tôi chỉ xếp được là xương thú hoặc xương động vật. Theo đó, với tổng số mảnh di cốt kể trên chúng tôi chỉ có thể phân loại được 1,153 mảnh, chiếm $22.93 \%$ (Bảng 1).

Bảng 2 cho thấy, vỏ nhuyễn thể xuất hiện ở tất cả các lớp khai quật nhưng số lượng của chúng giảm dần từ dưới lên các lớp mặt. Về thành phần, chủ yếu là các loài nhuyễn thể nước ngọt như ốc vặn (Sinotaia aeruginosa), trai, trùng trục ngắn (Oxynaia micheloti), và hến song (Corbicula fluminea). Nhóm ốc cạn chỉ có số lượng mẫu rất ít, chỉ vài cá thể cho thấy chúng không phải là nguồn dinh dưỡng ưa thích của cư dân ở 
đây, khác với các di chỉ tiền sử ở khu vực miền Bắc và bắc Miền Trung (Việt Nam), nơi ốc núi (Cyclophorus sp.) là đối tượng khai thác chính của con người (Bảng 2; Hình 5).

Bảng 1. Bảng tổng hợp phân loại xương răng động vật tại hố thám sát năm 2017

\begin{tabular}{|c|c|c|c|c|c|c|c|c|c|c|c|c|c|}
\hline Class/Order & Lớp đào & $\mathrm{LM}$ & L1 & L1.F1 & L2 & L3 & L3.F2 & L4 & L5 & L6 & L7 & L8 & Tổng \\
\hline Family/Species & Phân loại & & & & & & & & & & & & \\
\hline Mammalia & Lớp thú & 719 & 553 & 449 & 411 & 370 & 103 & 328 & 267 & 252 & 179 & 243 & 3,874 \\
\hline Chiroptera & Bộ dơi & 20 & 34 & 45 & 105 & 50 & 26 & 91 & 10 & 10 & 22 & 27 & 440 \\
\hline Pteropodidae & Dơi quạ & 1 & & & & & & & & & & & 1 \\
\hline Hipposideridae & Dơi mũi ba lá & & & 1 & & & & & & & & & 1 \\
\hline Artiodactyla & Bộ guốc chẵn & & & & & & & & & & & & \\
\hline Cervidae & Hươu nai & 3 & 7 & 8 & 10 & & & 8 & & 3 & 8 & 4 & 51 \\
\hline Axis porcinus & Hưou vàng & 2 & & & & 2 & & & & & & & 4 \\
\hline Suidae & & & & & & & & & & & & & \\
\hline Sus scrofa & Lơn & 8 & 11 & 7 & 8 & 3 & 1 & 1 & 1 & & 1 & & 41 \\
\hline Perissodactyla & Bộ guốc lẻ & & & & & & & & & & & & \\
\hline Rhinocerotidae & Tê giác & & 1 & & & & & & & & & & 1 \\
\hline Carnivora & Bộ ăn thịt & 3 & 3 & 1 & 1 & & & 1 & & & 1 & & 10 \\
\hline Felidae & Mèo? & & & 1 & & & & & & & & & 1 \\
\hline Primates & Bộ linh trưởng & & & & & & & & & & & & \\
\hline Cercopithecidae & Họ khỉ & 6 & 9 & 9 & 13 & 2 & & 1 & & 1 & 3 & 5 & 49 \\
\hline Rodentia & Bộ gặm nhấm & & & & & & & & & & & & \\
\hline Muridae & Chuột & & & 1 & & & & & & & & & 1 \\
\hline Hystricidae & Nhím & & 1 & 2 & & & & & & & & & 3 \\
\hline Aves & Chim & 4 & 11 & 12 & 14 & 6 & & 6 & & 7 & 5 & & 65 \\
\hline Testudinata & Rùa cạn & 3 & 43 & 42 & 44 & 67 & 26 & 14 & 17 & 7 & 9 & 21 & 323 \\
\hline Squamata & Bò sát có vảy & & & & & & & & & & & & \\
\hline Varanidae & Kỳ đà & 3 & 1 & 6 & & & & & & & & & 10 \\
\hline Pices & Cá & 21 & 26 & 21 & 19 & 8 & 2 & 9 & 4 & 2 & & & 112 \\
\hline \multirow[t]{2}{*}{ Công cụ xương } & Bone tool & 7 & 2 & & 8 & 9 & & 7 & 4 & 3 & & & 40 \\
\hline & Tổng & 830 & 702 & 605 & 633 & 517 & 158 & 466 & 303 & 285 & 228 & 300 & 5,027 \\
\hline
\end{tabular}

Có thể nói, hang C6-1 là di chỉ khảo cổ đầu tiên hiện biết ở khu vực Tây Nguyên tìm thấy nhiều di cốt động vật như vậy. Đây là nguồn tư liệu rất quan trọng để tìm hiểu điều kiện môi trường cũng như quá trình phát triển của người cổ trong khu vực. Các di cốt này cũng là những mẫu vật để có thang niên đại chính xác cho di chỉ. Tuy nhiên cần mở rộng quy mô khai quật trong hang C6-1 và cả ở các hang động khác trong hệ thống hang động núi lửa Krông Nô nhằm làm cơ sở so sánh chính xác và thuyết phục hơn. 
Bảng 2. Bảng tổng hợp phân loại vỏ nhuyễn thể tại hố thám sát năm 2017

\begin{tabular}{|c|c|c|c|c|c|c|c|c|c|c|c|}
\hline Class/Family/Species & Lớp khai quật & L1 & $\mathrm{L} 2$ & L3 & L3 F2 & $\mathrm{L} 4$ & L5 & L6 & L7 & L8 & Tổng \\
\hline \multicolumn{12}{|l|}{ Gastropoda } \\
\hline \multicolumn{12}{|l|}{ Cyclophoridae } \\
\hline Cyclophorus sp. & Ốc núi & 3 & 3 & 6 & 2 & 1 & & & & & 15 \\
\hline Pterocylos berthae & Ốc núi & & & & 1 & & 1 & & & & 2 \\
\hline \multicolumn{12}{|l|}{ Camaenidae } \\
\hline Camaena sp. & Ốc núi & & & & 1 & & & 1 & & 1 & 3 \\
\hline \multicolumn{12}{|l|}{ Thiaridae } \\
\hline Melanoides tubeculatus & Ốc suối & & & & 1 & 1 & 2 & & 1 & 1 & 6 \\
\hline \multicolumn{12}{|l|}{ Viviparidae } \\
\hline Angulyagra polyzoneta & Ốc đá & & 2 & & & 1 & & & & & 3 \\
\hline Sinotaia aeruginosa & $\hat{O} c$ vặn & 18 & 10 & 18 & 20 & 67 & 55 & 52 & 48 & 147 & 435 \\
\hline \multicolumn{12}{|l|}{ Ampullariidae } \\
\hline Pila conica & Ốc buơu & & 1 & & & & & & & & 1 \\
\hline \multicolumn{12}{|l|}{ Bivalvia } \\
\hline Unioinidae & Trai & 3 & 7 & 5 & 2 & 1 & & 5 & 3 & 1 & 27 \\
\hline Oxynaia micheloti & Trùng trục & 4 & & & 1 & 7 & 18 & 22 & 10 & 22 & 84 \\
\hline \multicolumn{12}{|l|}{ Corbiculidae } \\
\hline \multirow[t]{2}{*}{ Corbicula fluminea } & Hến sông & & & & 2 & 1 & 7 & 2 & 4 & 10 & 26 \\
\hline & Tổng & 28 & 23 & 29 & 30 & 79 & 83 & 82 & 66 & 182 & 602 \\
\hline
\end{tabular}

Những nghiên cứu bước đầu cũng cho thấy tỷ lệ hàm lượng các khoáng vật carbonat rất cao, đặc biệt của khoáng vật calcit, là nhân tố chính bảo tồn xương cốt động vật nói chung và con người nói riêng cũng như vỏ các loài nhuyễn thể không bị tiêu hủy trong hang động núi lửa. Sự dao động về tỷ lệ thành phần vật chất này sẽ góp phần lý giải sự tham gia của con người trong địa tầng ở các thời điểm khác nhau, hay sự tương thích của con người tiền sử với những biến động môi trường, khí hậu, cảnh quan.

\subsubsection{Di vật}

Di vật thu được ở hang C6-1 khá đa dạng và phong phú, bao gồm đồ đá, đồ gốm, xương và vỏ nhuyễn thể. Ngoài số hiện vật thu được trong hố khai quật, chúng tôi còn thu thập được một lượng tương đối hiện vật đá trên bề mặt di tích trong quá trình thám sát. Di vật đá trong hố thám sát có 676 di vật, được chia thành các loại: Công cụ lao động, phác vật hình rìu, nhóm phế liệu, nguyên liệu (Bảng 3).

Nhóm công cu lao động: Có 16 hiện vật, chiếm $2.37 \%$ tổng số di vật đá của hố thám sát. Công cụ lao động có những loại hình và đặc điểm dưới đây: 
- Công cu chặt: Có 3 tiêu bản, chế tác từ cuội basalte, hình khối chữ nhật hoặc khối tam diện. Phần đốc cầm của công cụ thường tận dụng 1 đầu còn bảo lưu vỏ cuội tự nhiên, ghè thô một hoặc hai mặt tạo thành 1 rìa tác dụng. Những công cụ chặt ở đây có kích thước nhỏ, vừa tay cầm, được làm từ cuội basalte. Chúng thường có một rìa tác dụng và một đốc cầm. Chức năng của những công cụ này có thể dùng chặt cây, xẻ thịt động vật săn bắt được (Hình 6a).

- Công cu nạo hình đĩa (gần tròn). Có 2 tiêu bản. Tiêu bản thứ nhất được chế tác từ cuội cát kết mịn, thân gần tròn, có hai mặt lớn phẳng, một mặt còn vỏ cuội tự nhiên, mặt đối diện là mặt âm của một mảnh tước tách ra từ viên đá khác lớn hơn. Vết ghè tạo rìa tác dụng xung quanh, gần tròn, ghè một mặt, tập trung ở một đoạn rìa cạnh tác dụng. Kích thước: Dài $6.5 \mathrm{~cm}$, rộng 6.4 $\mathrm{cm}$, dày $1.7 \mathrm{~cm}$ (Hình $6 \mathrm{~d}$ ). Tiêu bản thứ 2 chế tác từ cuội sét silic, hình đĩa gần tròn, hai mặt bên phẳng, vuông góc với nhau hợp thành đốc. Rìa cạnh còn lại có vết ghè chủ yếu một mặt, tạo thành hai rìa tác dụng lượn cong. Kích thước: Dài $5.6 \mathrm{~cm}$, rộng $6.2 \mathrm{~cm}$, dày $2.8 \mathrm{~cm}$ (Hình $6 \mathrm{c}$ ).

- C Công cu hình rìu ngắn: Phát hiện được 1 tiêu bản duy nhất, ký hiệu17.C61.L7.D4: 23, chế tác từ đá phiến (schiste silic), còn nguyên vẹn. Công cụ có hình rìu ngắn, loe rộng về phía rìa lưỡi, đốc phẳng, các mặt lớn cong lồi. Rìa cạnh và rìa lưỡi mỏng, có vết ghè hai mặt, rìa lưỡi lượn cong. Kích thước: Dài $9.1 \mathrm{~cm}$, rộng $7.8 \mathrm{~cm}$, dày $3.8 \mathrm{~cm}$.

- Công cụ cắt hình bàn là: Có 1 tiêu bản duy nhất, ký hiệu 17.C6-1.L7.D4: 24, chế tác từ đá basalte, hình khối tam giác, thuôn nhọn về phía hai đầu. Một mặt của công cụ còn vỏ cuội, hai mặt đối có các vết ghè tạo rìa cạnh, hướng tâm, ghè lan thân, bóc lớp vỏ cuội tạo thành 3 đường rìa mới. Trong đó, 1 rìa mỏng, chạy dài, có vết sử dụng dạng dao cắt. Kích thước: Thân dài $10.6 \mathrm{~cm}$, rộng $5.5 \mathrm{~cm}$, dày $3.9 \mathrm{~cm}$ (Hình $6 \mathrm{~b}$ ).

- Mảnh rìu: Là những mảnh vỡ ngang thân công cụ. Trong hố thám sát đã phát hiện được 4 mảnh, phân bố chủ yếu ở ở L1.F1 và lớp 2.

- Công cu mảnh: Có 2 tiêu bản. Các công cụ được tận dụng từ các mảnh tước kích thước lớn bằng đá basalte, ghè tu chỉnh tạo rìa tác dụng.

- Hòn ghè: Có 2 tiêu bản. Tiêu bản thứ nhất là một viên cuội sông, dẹp, hình bầu dục, hai đầu thuôn có vết vỡ do ghè vật cứng; Tiêu bản thứ hai là một viên cuội sông, hình bầu dục, hai đầu có dấu vết sử dụng để ghè vật cứng. Loại hình hiện vật này có thể dùng để nghiền hạt hoặc là dụng cụ dùng để chế tác đồ đá.

- Bàn mài: Trong hố thám sát chỉ có 1 tiêu bản, ký hiệu 17.C6-1.L2.D3: 10, nguyên liệu là đá basalte, hình tứ giác. Bàn mài đã bị vỡ chỉ còn một phần, một mặt phẳng có vết mài lõm, mặt đối diện có vết kề lõm sâu vào thân. 


\begin{tabular}{llll} 
Bảng 3. Thống kê tổng họ̣p hiện vật đá hố thám sát hang C6-1 \\
\hline Lhóm & Loại & Số lượng & Tổng cộng \\
\hline & Công cụ chặt & 3 & \\
& Công cụ hình đĩa & 2 & \\
& Công cụ hình bàn là & 1 & \\
Công cụ lao động & Hình rìu ngắn & 1 & $16(2.37 \%)$ \\
& Mảnh rìu & 4 & \\
& Công cụ mảnh & 2 & \\
& Hòn ghè & 2 & \\
& Bàn mài & 1 & $2(0.30 \%)$ \\
\hline Phác vật & Đá có vết ghè & 1 & \\
\hline \multirow{4}{*}{ Phế liệu } & Phác vật rìu & 1 & 658 (97.33\%) \\
\hline Tổng cộng & Mảnh tước & 651 & \\
\hline & Hạch đá & 2 & \\
\hline & Đá nguyên liệu & 5 & 676 \\
\hline
\end{tabular}

Nhóm phác vật rìu đá: Có 2 tiêu bản. Chiếc thứ nhất là phác vật chỉ được ghè sơ qua, dạng sơ chế, chưa rõ làm loại rìu gì; Chiếc thứ hai vết ghè rõ ràng hơn, mang chủ đích tạo ra rìu tứ giác. Cả hai phác vật đều có kích thước nhỏ, trên thân còn để lại lỗi kỹ thuật nên người tiền sử không tiếp tục ghè hoàn thiện và bỏ lại nơi cư trú.

Nhìn chung, sự xuất hiện và tương đồng về loại hình lẫn kích thước, chất liệu của các công cụ hoàn chỉnh, các công cự phục vụ hoạt động chế tác đồ đá, phác vật, mảnh tước và đá nguyên liệu cho thấy cư dân hang C6-1 chế tác công cụ đá tại chỗ phục vụ nhu cầu của bản thân cộng đồng. Cư dân tiền sử đã khai thác nguồn nguyên liệu cuội sông, suối phân bố gần hang động. Chất liệu chủ yếu là cuội đá basalte, schiste silic, phiến sét, quarite và hiếm hơn là đá opal. Bên cạnh kỹ thuật ghè đẽo là chủ đạo, kỹ thuật mài cũng đã xuất hiện và hiện hữu ở các công cụ mức trên.

Nhóm phế liệu: Có 658 tiêu bản, trong đó có 2 hạch đá, 651 mảnh tước và 5 đá nguyên liệu, chúng có một số đặc điểm sau:

- Hạch đá: Có 2 tiêu bản. Tiêu bản thứ nhất được làm từ đá basalte, thân hình tứ giác, một đầu thuôn, bề mặt phẳng, các mặt bên là mặt âm bản của các vết ghè kích thước lớn. Tại đầu thuôn có các vết ghè nhỏ. Sau khi tách mảnh tước, hạch đá còn lại có thể sử dụng như một công cụ mũi nhọn (bị gãy). Kích thước: Dài $7.5 \mathrm{~cm}$, rộng $4.9 \mathrm{~cm}$, dày $4.1 \mathrm{~cm}$. Tiêu bản thứ 2 được làm từ đá basalte, có thân hình trụ đa diện, hai mặt lớn song song nhau, mặt 
bên phẳng, là mặt âm bản vết ghè tách mảnh. Kích thước: Dài $4.7 \mathrm{~cm}$, rộng $7.2 \mathrm{~cm}$, dày $6.8 \mathrm{~cm}$.

- Mảnh tước: Có số lượng 651 mảnh, phân bố ở hầu khắp các độ sâu, chất liệu chủ yếu là đá basalte 608 mảnh, đá quartz có 36 mảnh, ít nhất là đá opal 7 mảnh. Phân loại cho thấy cư dân hang động C6-1 chế tác và sử dụng chủ yếu là đá basalte. Đây là một trong những đặc trưng quan trọng của cư dân tiền sử ở đây. Như chúng ta đã biết, đá basalte thường dẻo, dễ ghè, khi ghè có thể tạo ra một rìa lưỡi mỏng, sắc với độ cứng trung bình. Công cụ được làm từ loại đá này có thể dùng để cắt, chặt loại cây gỗ mềm, xẻ thịt động vật, hoặc cắt hái cây cỏ. Mảnh tước làm từ đá quartz và opal ở hang C6-1 rất ít, cho thấy 2 loại đá này không phải là đối tượng chính để chế tác công cụ. Thông thường cuội đá quartz dùng để làm hòn ghè, hòn đập, còn đá opal dùng chế tác rìu, mảnh tước của chúng rất sắc có thể dùng làm dao cắt. Sảm phẩm rìu đá có chất liệu opal thường gặp trong các di chỉ xưởng hậu kỳ Đá mới Tây Nguyên, trong các hang ở Krông Nô chưa thấy những chiếc rìu làm từ đá này.

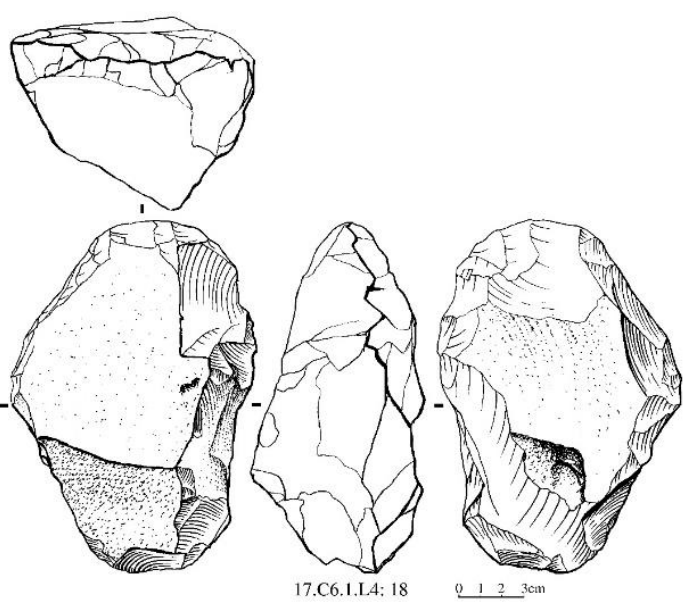

(a)

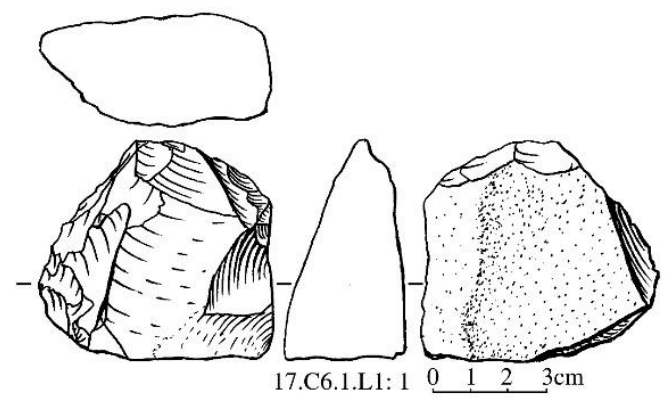

(c)
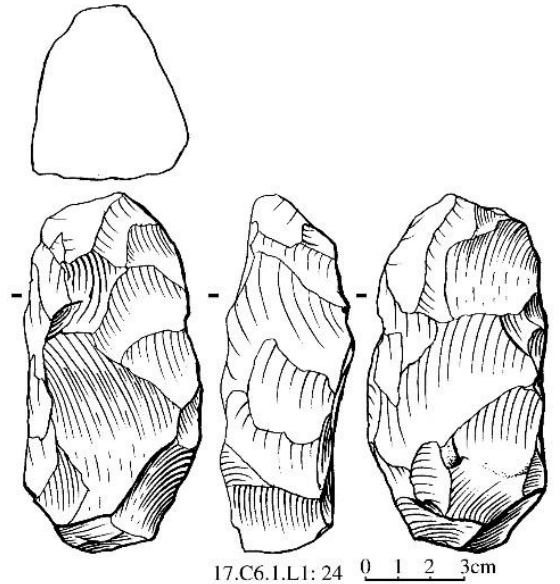

(b)
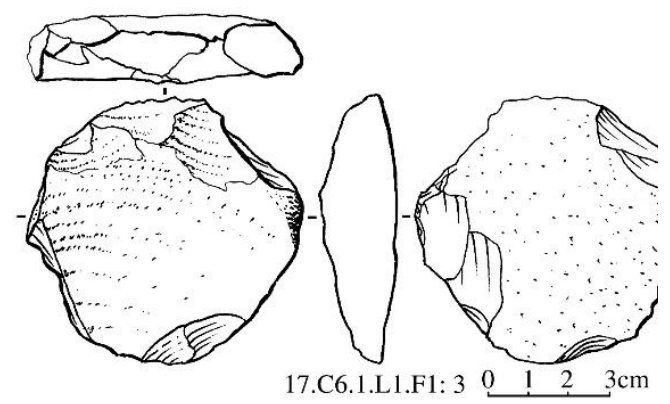

(d)

Hình 6. Công cụ đá ở hang C6-1 Krông Nô

Ghi chú: a) Công cụ đá hố C6, lớp 4; b) Công cụ hình bàn là, đá basalte; c) Công cụ nạo gần hình đĩa, đá cuội sét silic; và d) Công cụ hình đĩa, đá grèse mịn. 
Đồ gốm: Trong hố thám sát $2 \mathrm{~m}^{2}$ đã tìm thấy 268 mảnh gốm (132 mảnh ở lớp mặt và 133 mảnh ở lớp 1 , các lớp dưới sót lại 2 mảnh ở lớp 3 và 1 mảnh ở lớp 4). Gốm bị gãy vỡ nhỏ, hầu như không còn nguyên trạng mảnh miệng hoặc mảnh đế. Do vậy, rất khó phục chế kiểu dáng ban đầu. Chất liệu, loại hình, hoa văn và kỹ thuật chế tác gốm các lớp là giống nhau, nên có thể xem như một sưu tập gốm thống nhất. Về chất liệu, gốm làm từ đất sét, pha rất ít cát, hạt nhỏ nên xương gốm mịn. Xương gốm màu nâu, đôi khi hơi nâu vàng. Thành gốm mỏng, trung bình $0.2 \mathrm{~cm}-0.3 \mathrm{~cm}$. Phần lớn các mảnh gốm đều được miết láng cả 2 mặt đối với mảnh không hoa văn và miết láng mặt trong, còn mặt ngoài văn thừng chải. Vết thừng lăn nhỏ và đều (gọi chung là thừng mịn), chỉ gặp vết thừng thô ở vai đồ đựng, nơi vai gốm nhô ra. Trong số 60 mảnh quan sát thấy một số mảnh nét thừng nhỏ, sâu và sắc nét; có 1 mảnh văn chải cắt vuông góc với nhau tạo ra các đường bị cắt khía, lồi, lõm xen kẽ nhau. Về kỹ thuật: Gốm cứng, mỏng đều, cho thấy chúng được nung ở nhiệt độ khá cao. Quan sát 2 mảnh thân có thể đồ đựng này có đường kính thân không lớn, khoảng $15 \mathrm{~cm}$. Ngoài một số mảnh màu nâu, miết láng bóng có thể liên quan đến đồ đựng dạng bát bồng, có một số mảnh mặt gốm đen, ám khói có thể sử dụng cho việc đun nẩu như nồi.

Đồ đồng: Trong hố thám sát chỉ phát hiện 1 tiêu bản mũi tên ký hiệu là 17.C61.LM: 30 , chất liệu là hợp kim đồng, phong hóa màu xanh và còn nguyên vẹn. Thân hình tam giác có 2 ngạnh, mỏng, chế tác bằng kỹ thuật đúc. Đầu ngạnh cách nhau $1.5 \mathrm{~cm}$, chuôi dài $1.7 \mathrm{~cm}$. Đây là loại hình di vật xuất hiện trong các di tích thuộc thời đại Kim khí có trình độ luyện kim phát triển cao.

Công cu mũi nhọn bằng xuơng: Phân bố từ lớp 4 trở xuống (độ sâu $40 \mathrm{~cm}$ ) của hố thám sát, trong các lớp này đã phát hiện 20 công cụ mũi nhọn được mài (Hình 5i). Các mũi nhọn đều là những mảnh xương chi động vật loại nhỏ, hình trụ dài, một đầu vuốt nhọn, mài toàn thân. Kích thước trung bình dài $2 \mathrm{~cm}$, rộng $0.5 \mathrm{~cm}$, dày $0.2 \mathrm{~cm}$. Đây là loại hình công cụ khá độc đáo và hiếm thấy trong các di tích tiền sử trên địa bàn Tây Nguyên. Loại hình di vật này cung cấp những tư liệu mới nhất về môi trường tự nhiên và cách thức khai thác tài nguyên thiên nhiên của cư dân Tiền - Sơ sử Tây Nguyên.

Các mẫu trầm tích địa tầng: Để nắm rõ về quá trình hình thành trầm tích trong hang, chúng tôi đã lấy 4 mẫu đất từ địa tầng hố thám sát hang C6-1 và chuyển cho GS.TS. Tạ Hòa Phương phân tích thành phần trầm tích. Các mẫu này có ký hiệu M1, $\mathrm{M} 2, \mathrm{M} 3$, và M4. Kết quả phân tích trầm tích địa tầng khảo cổ hang C6-1 cho thấy thành phần hóa học giữa các lớp trầm tích theo độ sâu của địa tầng hang động này biến động không nhiều. Đáng kể nhất là $\mathrm{CaO}$ có hàm lượng cao $(50.51-60.10 \%)$ và $\mathrm{SiO}_{2}=8.70-$ $13.03 \%$, các thành phần phụ như $\mathrm{Al}_{2} \mathrm{O}_{3}, \mathrm{FeO}^{*}, \mathrm{P}_{2} \mathrm{O}_{5}$, và $\mathrm{MgO}$ có hàm lượng $<5 \%$ và không thay đổi nhiều giữa các lớp. Hợp phần khoáng vật chủ yếu ở các tầng trầm tích chứa di tích khảo cổ trong địa tầng hang C6-1 là các khoáng vật carbonat. Trong đó, calcit là pha khoáng vật có hàm lượng cao nhất, tiếp theo là aragonit, calcium silicat, dolomit, witherit, cerrusit. Các khoáng vật carbonat có xu hướng tập trung với hàm lượng lớn hơn ở tầng trầm tích $\mathrm{M} 2$ và $\mathrm{M} 3$ (>90\%), ở tầng trầm tích của mẫu $\mathrm{M} 1$ và $\mathrm{M} 4$ hàm lượng các khoáng vật này tuy không cao như ở mẫu $\mathrm{M} 2$ và $\mathrm{M} 3$ nhưng cũng chiếm tới > 70\% (calcit trong M1 là 72.3\% và trong M4 là 79.0\%) (Tạ \& ctg., 2018). 


\section{MỘT VÀI NHận THỨC VÀ THẢO LUẬN}

Từ kết quả nghiên cứu đặc trưng di tích và di vật của hố thám sát, so sánh với những kết quả khảo sát di tích trong các hang động ở Krông Nô, chúng tôi đưa ra một số nhận thức và thảo luận như sau:

- Về phân bố loại hình công cu đá: Trong độ sâu từ $80 \mathrm{~cm}-30 \mathrm{~cm}$ (mức sớm) xuất hiện những công cụ làm từ cuội sông, suối. Ở giai đoạn này, công cụ đá chủ yếu là loại ghè đẽo, đã xuất hiện rìu mài lưỡi, loại hình đặc trưng là rìu hình bầu dục, công cụ thắt eo hai bên, công cụ hình đãa, rìu ngắn. Con dao, cái nạo và những công cụ mảnh tước nhỏ và mỏng, cùng hòn ghè, chày nghiền, hòn kê. Đây là những công cụ thường gặp trong các di tích trung kỳ Đá mới, cách nay khoảng 6,000 - 5,000 năm BP. Sang giai đoạn muộn, ở độ sâu từ lớp mặt xuống $30 \mathrm{~cm}$, bên cạnh một số công cụ ghè đẽo như mức sớm nhưng đã xuất hiện những chiếc rìu tứ giác mài toàn thân, bàn mài. Đây là những di vật thường gặp trong các di tích hậu kỳ Đá mới và sơ kỳ Kim khí, cách nay khoảng 5,000 đến trên dưới 4,000 năm BP.

- Phân loại tổ hợp mảnh tước: Trong số 651 mảnh tước được phân loại theo kích thước (chia thành 5 khoảng) cho kết quả sau: Mảnh tước nhỏ dưới $2 \mathrm{~cm}$ chiếm tuyệt đối 299 mảnh $(45.7 \%)$, từ $2.0-2.9 \mathrm{~cm}$ có 174 mảnh (chiếm 27.14\%), loại 3.0 - 3.9 có 99 mảnh (chiếm $15.18 \%$ ), từ $4.0-4.9 \mathrm{~cm}$ có 63 mảnh (chiếm 9.5\%), trên $5 \mathrm{~cm}$ rất ít chỉ có 16 mảnh (chiếm 2.45\%). Kích thước mảnh tước ở đây tương ứng với mặt âm của công cụ đá, trong lúc hạch đá rất ít (2 hạch). Từ đây có thể xác định, hầu hết các mảnh tước này được tách ra trong quá trình chế tác công cụ đá. Với số lượng lớn mảnh tước, có thể nói đây là nơi vừa cư trú, vừa chế tác công cụ, dạng cư trú xưởng. Với số lượng áp đảo mảnh tước nhỏ ở trong sưu tập cho biết, kỹ thuật ghè nhỏ, ghè tu chỉnh phát triển mạnh ở giai đoạn này.

- Về đồ gốm: So sánh đồ gốm ở hang C6-1 với gốm hiện biết trên địa bàn Đắk Nông và Tây Nguyên, xác nhận gốm ở đây có chất liệu và kỹ thuật chế tác có nét gần với đồ gốm địa điểm Buôn Triết và Đắk R'lấp. Tuy nhiên, gốm cứng hơn, chế tác ở trình độ cao hơn, nhất là độ mỏng, nhưng rất cứng; Trang trí văn thừng, văn chải sắc nét và các dấu miết láng không bị bong tróc như các di tích nói trên. Những đồ gốm ở đây có thể đại diện cho giai đoạn phát triển cao của cư dân hang C6-1, vì chúng chỉ gặp ở lớp 1 và lớp mặt, độ sâu không quá $30 \mathrm{~cm}$. Trong mức này ngoài công cụ đá mài toàn thân còn tìm thấy mũi tên đồng. Cũng lưu ý thêm, phần lớn các mảnh gốm này tìm thấy ở hố rác bếp $\mathrm{F} 1, \mathrm{~F} 2$ nơi người nguyên thủy sử dụng để đun nấu, ăn uống, sinh hoạt, rồi bị vỡ ra và bỏ lại trong hang.

- Kết quả nghiên cứu, phân loại nhóm động vật cho thấy: Thành phần các nhóm loài sinh vật có mặt khá đều ở các lớp khai quật. Số lượng di cốt tăng dần từ các lớp dưới đến các lớp mặt, đặc điểm này gợi ý sự ổn định về môi trường sống khu vực trong suốt quá trình cư trú của người cổ ở di chỉ. Tuy 
nhiên, cần có được những kiểm chứng trong các đợt khai quật mở rộng. Trong số các di cốt định loài được, xương dơi chiếm tỉ lệ lớn nhất $38.16 \%$, trong đó có họ dơi quạ (Pteropodidae) và Họ dơi mũi ba lá (Hipposideridae). Bộ thú móng guốc chẵn có xương răng của Hươu/nai, hươu vàng (Axis porcinus) và lợn (Sus scrofa). Trong hố thám sát, xương khỉ chiếm tî̉ lệ lớn, tương đương với các loài thú móng guốc, đây là điểm khá khác biệt so với các di chỉ thời tiền sử đã phát hiện ở khu vực miền Bắc và Bắc Miền Trung, Việt Nam. Mảnh mai, yếm và các xương dài của rùa tìm thấy ở tất cả các lớp khai quật với số lượng lớn chiếm tới $28.01 \%$ trong tổng số mảnh xương định loại được (Hình 5). Nhiều mảnh xương, mai rùa có dấu vết bị cháy, là đối tượng săn bắt của người nguyên thủy. Xương chim có số lượng mảnh rất nhiều, dù không được phân loại tới mức họ/loài. Điều này khác với các di chỉ hang động ở khu vực miền Bắc, nơi chỉ tìm thấy vài mảnh xương chim. Xương cá cũng rất phổ biến trong tầng văn hóa (Hình 5). Các nhóm thú ăn thịt, thú gặm nhấm chỉ ghi nhận được với số lượng mẫu ít nên khó có nhận xét so sánh xác đáng giữa các lớp đào cũng như với các di chỉ khác. Tê giác là loại thú lớn nhất đã tìm thấy trong quần động vật ở hang C6-1 (Hình 5).

- Kết quả phân tích trầm tích: Tạ và ctg. (2018) cho rằng, lần đầu tiên giới khoa học Việt Nam tìm thấy di tích khảo cổ tiền sử hang động núi lửa, ở đó hầu như toàn bộ di tồn hữu cơ còn được bảo tồn trong địa tầng. Phát hiện này mở ra triển vọng lớn trong nghiên cứu lịch sử nhân loại, cổ môi trường kỷ Đệ tứ ở vùng đất basalt Tây Nguyên rộng lớn. Kết quả nghiên cứu ban đầu cho thấy yếu tố cho phép bảo tồn những tàn tích động-thực vật là rất tốt. Đây là triển vọng mở ra việc phát hiện hóa thạch người và động vật cổ xưa của nhân loại có khả năng được bảo tồn trong hệ thống trên 100 hang động núi lửa khác ở Tây Nguyên trong tương lai.

Từ những kết quả nghiên cứu trên cho thấy cư dân tiền sử đã chiếm lĩnh hang này từ khá sớm, ít nhất là từ trung kỳ Đá mới, cách nay khoảng 6,000 năm $\mathrm{BP}$ và kết thúc vào khoảng trên dưới 4,000 năm BP với hai giai đoạn văn hóa:

- Tài liệu địa tầng hố thám sát cho biết, vào giai đoạn sớm, từ $6,000-5,000$ năm BP (tương ứng từ lớp 8 đến lớp 4 ), con người chế tác công cụ từ những viên cuội sông, suối với chất liệu cứng và độ dẻo cao như các loại đá chert, đá phiến silic, quartzite, thạch anh là chính. Họ cũng bắt đầu chể tác và sử dụng công cụ làm từ đá basalte. Ở giai đoạn này, con người chủ yếu sử dụng kỹ thuật ghè trực tiếp (đá ghè đá), ghè trên một hoặc hai mặt để tạo ra những chiếc rìu hình bầu dục, công cụ thắt eo hai bên, công cụ hình đĩa, rìu ngắn... Bằng việc sử dụng kỹ thuật bổ cuội, người xưa đã làm ra những con dao cắt, những cái nạo, những mũi nhọn từ mảnh tước với dấu tu chỉnh nhỏ. Họ thường sử dụng những viên cuội sông để làm hòn ghè, chày nghiền, hòn kê, bàn mài. Bằng thực nghiệm và quan sát dân tộc học so sánh, các nhà khảo cổ cho biết những công cụ này có thể sử dụng vào việc chặt cây, phát 
rừng, xẻ thịt con thú, cắt thái các loài thảo mộc, chế biến thực phẩm hoặc gia công tre gỗ làm công cụ và vũ khí săn bắt.

- Sang giai đoạn muộn, từ lớp mặt đến lớp 4, niên đại khoảng 5,000 năm BP đến trên dưới 4,000 năm $\mathrm{BP}$, con người chế tác và sử dụng một số công cụ ghè đẽo như giai đoạn sớm, nhưng bắt đầu xuất hiện những chiếc rìu tứ giác được mài toàn thân, công cụ mũi nhọn bằng xương, mũi tên có ngạnh bằng kim loại, đặc biệt là sự xuất hiện đồ gốm đất nung. Đồ gốm ở đây được làm từ đất sét pha cát, hạt nhỏ, nặn tay, loại hình đơn giản, chủ yếu là nồi, bát, bình nhỏ, xương gốm mỏng; một số có lớp áo phủ, một số trang trí văn đập, văn in ô vuông, văn khắc vạch, in chấm. Đây là những di vật thường gặp trong các di tích hậu kỳ Đá mới - sơ kỳ Kim khí ở Tây Nguyên.

Hố thám sát chưa kết thúc, tạm dừng ở độ sâu $80 \mathrm{~cm}$. Nhưng, khả năng tìm thấy lớp sớm hơn là rõ ràng. Do bề mặt đáy hố thám sát hiện cao hơn bề mặt lòng hang khoảng $2.5 \mathrm{~m}$, nên có khả năng hố thám sát còn có độ sâu trên $1.5 \mathrm{~m}$. Phần còn lại của hố thám sát có thể là đại diện cho lớp văn hóa sớm hơn, bởi vì trên bề mặt lòng hang đã phát hiện rất nhiều công cụ cuội ghè đẽo thô sơ, kích thước lớn, được làm từ đá quartzit, quartz với các loại hình như công cụ chặt thô (chopper, choping), những mũi nhọn lớn (point), những cái nạo hình đĩa, những chiếc rìu hình bầu dục... vốn đặc trưng cho giai đoạn sơ kỳ Đá mới.

Ngoài ra, với những cấu trúc đá xếp hình tròn phát hiện ở hang C6-1 và C6' rất có thể liên quan đến mộ táng. Điều đó gợi mở, trong hang động vùng núi lửa ở Krông Nô còn bảo lưu dấu tích mộ táng, vấn đề này cần tiếp tục nghiên cứu. Nhưng, chắc chắn rằng, trong một số hang động ở đây lưu giữ các hoạt động sống của các bộ tộc thời tiền sử với các lớp người kế tiếp nhau, sớm nhất có thể là sơ kỳ Đá mới, tương đương với sơ kỳ Holocene, tiếp sau là cư dân trung kỳ Đá mới, tương đương với trung kỳ Holocene, cách đây khoảng $6,000-7,000$ năm $\mathrm{BP}$, và cuối cùng con người rời hang vào hậu kỳ Đá mới - sơ kỳ Kim khí, cách đây khoảng trên dưới 4,000 năm $B P$. Những phát hiện và nghiên cứu này ghi nhận lần đầu tiên giới khoa học Việt Nam đã phát hiện ra các di tích cư trú của người tiền sử trong các hang động núi lửa basalte. Bổ sung thêm một loại hình cư trú mới, một kiểu thích ứng mới của cư dân tiền sử ở vùng đất đỏ basalte ở Tây Nguyên (Việt Nam). Đây là bằng chứng rõ ràng về lịch sử chiếm lĩnh và làm chủ vùng đất núi lửa trong đó có các hang động núi lửa nổi tiếng ở Krông Nô của cư dân tiền sử. Các di sản khảo cổ hang động ở đây cùng với giá trị hệ thống hang động núi lửa đóng góp một bằng chứng có tính thuyết phục cao cho việc xây dựng công viên địa chất toàn cầu ở Đắk Nông.

\section{KẾT LUẬN}

Trong khuôn viên KVG ở Krông Nô (Đắk Nông), các nhà địa chất đã phát hiện một hệ thống hang động có giá trị nghiên cứu di sản địa chất hang động núi lửa độc đáo ở Việt Nam. Cũng ở khu vực này, các nhà địa chất và khảo cổ bước đầu tìm thấy ở khu $\mathrm{C}$, một số các hang động từ $\mathrm{C} 1$ đến C6-1 có dấu tích cư trú, chế tác công cụ của người 
thời nguyên thủy. Đây cũng là những phát hiện khảo cổ học hang động núi lửa tiền sử đầu tiên ở Việt Nam và Đông Nam Á.

Cư dân tiền sử đã chọn lựa một số hang động núi lửa basalte để cư trú như "ngôi nhà” lý tưởng của mình. Đó là các hang có diện tích tương đối rộng, nền hang khá bằng phẳng, thông thoáng, đã có sự ổn định về độ gắn kết trần hang. Các hang này có cửa rộng, nhiều ánh sáng, cửa quay về hướng Tây Nam, hướng tiếp nhận được nhiều ánh sáng mặt trời vào buổi chiều. Đường lên xuống các hang dễ dàng, lại phân bố ở gần nguồn nước sinh hoạt. Những dấu tích văn hóa còn lại ở các hang cho thấy có hang được người xưa cư trú lâu dài, tầng văn hóa dày, phản ánh nhiều giai đoạn văn hóa khác nhau như hang C6-1. Lại có một số hang tầng văn hóa mỏng, do con người cư trú ngắn ngày hoặc cư trú theo mùa, như hang $\mathrm{C} 3, \mathrm{C} 4$. Lại có hang cư dân cổ sử dụng làm khu mộ táng, mộ kè đá (?) như hang C6-1 (cửa 3, quay về hướng Đông Bắc ), hang C6'. Tư liệu này cho thấy hệ thống các hang động ở đây được người xưa lựa chọn vì các mục đích khác nhau. Cư dân ở hang động vùng Krông Nô là những người săn bắt, hái lượm, chưa có dấu hiệu của trồng trọt và chăn nuôi. Ở giai đoạn sớm, con người đã săn bắt được một số loài động vật nhỏ, một ít động vật lớn như hươu, nai, lợn, đồng thời đánh bắt cá và thu lượm các loài nhuyễn thể như ốc, hến, trai, trùng trục trong các sông suối, đầm lầy. Sang giai đoạn muộn, săn bắt động vật và thu lượm các loài nhuyễn thể như giai đoạn trước, song kích thước của chúng nhỏ hơn, số lượng loài ít phong phú bằng giai đoạn sớm. Trong hố thám sát nhỏ, nhưng đã thu được hàng nghìn mẫu vật minh chứng cho sự thay đổi môi trường và sự tương thích của con người trong các hoạt động kiếm sống ở đây.

Những phát hiện, thám sát và nghiên cứu về mặt khảo cổ học nói trên mới chỉ là những phát hiện ban đầu, chúng tôi trân trọng đề nghị Bảo tàng Thiên nhiên Việt Nam, Viện Hàn lâm Khoa học và Công nghệ Việt Nam, Sở Khoa học và Công nghệ tỉnh Đắk Nông, UBND tỉnh Đắk Nông, và Bộ Khoa học và Công nghệ cho phép xây dựng Hồ sơ dự án điều tra, tìm kiếm, thẩm định và khai quật mở rộng các di tích khảo cổ hang động ở tỉnh Đắk Nông. Những hoạt động này sẽ đóng góp tích cực cho việc nghiên cứu diễn trình lịch sử văn hóa các cộng đồng cư dân tiền sử trên đất Đắk Nông nói riêng và Tây Nguyên nói chung. Xây dựng hồ sơ công viên địa chất toàn cầu cho khu vực KVG, góp phần bảo tồn và phát huy di sản văn hóa khảo cổ dân tộc, xây dựng du lịch Đắk Nông trở thành ngành kinh tế mũi nhọn, góp phần phát triển kinh tế xã hội ở tỉnh Đắk Nông.

\section{LÒ̀I CẢM ONN}

Bài báo này được hoàn thành trong quá trình thực hiện đề tài khoa học mã số TN17/T06, Bảo tàng Thiên nhiên Việt Nam - Viện Hàn lâm Khoa học và Công nghệ Việt Nam, do TS. La Thế Phúc làm chủ nhiệm.

\section{TÀI LIỆU THAM KHẢO}

La, T. P., Tachihara, H., Honda, T., Trương, Q. Q., \& Lương, T. T. (2015). Di sản địa chất hang động núi lửa độc đáo ở Đắk Nông đã được phát hiện và xác lập kỷ lục. Tạp chi Địa chất, A(349), 28-38. 
La, T. P., Nguyen, K. S., Vu, T. D., Luong, T. T., Phan, T. T., Nguyen, T. T., \& Nguyen, T. M. (2017). New discovery of prehistoric archaeological remnants in volcanic caves in Krongno, Daknong Province. Vietnam Journal of Earth Sciences, 39(2), 97-108.

Nguyễn, K. S., Nguyễn, G. Đ., Nguyễn, T. Đ., Phan, T. T., Lê, H. Đ., \& Lê, X. H. (2016). Khảo cổ học tiê̂n sủ miền Trung Việt Nam. Hà Nội, Việt Nam: NXB. Khoa học Xã hội.

Nguyễn, K. S., Phan, T. T., Lê, X. H., \& Vũ, T. Đ. (2017). Báo cáo kết quả đào thám sát hang C6-1 ở Krông Nô, tỉnh Đắk Nông. Hà Nội, Việt Nam: Viện Khảo cổ học.

Tạ, H. P., Nguyễn, T. D., Nguyễn, T. A. N., \& Phan, T. T. (2018). Phân tích trầm tích di chỉ tiền sử hang động núi lửa C6-1 (Đắk Nông). Trong Nhũng phát hiện mói về Khảo cổ học năm 2017. Hà Nội, Việt Nam: NXB. Khoa học Xã hội.

UNESCO. (2009). Global Geopark network. Retrieved from http://unesdoc.unesco.org/ images/0015/001500/150007e.pdf. 